Semião, A. ; Rossiter, H.M.A. ; Schäfer, A.I. ; (2010) Impact of organic matter and speciation on the behaviour of uranium in submerged ultrafiltration, Journal of Membrane Science, 348, 1-2, 174-180. doi:10.1016/j.memsci.2009.10.056

\section{Impact of organic matter and speciation on the behaviour of uranium in submerged ultrafiltration}

\author{
Submitted to
}

Journal of Membrane Science

June, 2009

Engineering, The University of Edinburgh,

Edinburgh, EH9 3JL, United Kingdom

* Corresponding author: Andrea Schäfer, E-mail: Andrea.Schaefer@ed.ac.uk, Phone: +44 (0)131 650 7209, Fax: +44(0) 1316506781

\section{Abstract}

Influence of organic matter $(O M)$ on uranium removal mechanisms by ultrafiltration (UF) over a pH range of 3-11 were investigated. Humic, alginic and tannic acid were used as OM. It was found that uranium adsorbed strongly to the membrane while retention by size exclusion did not occur. Adsorption was dependent on $\mathrm{pH}$ and type of $\mathrm{OM}$ used. Speciation predictions performed using visual Minteq explain some of these results. In the absence of OM, uranium primarily adsorbed to the membrane at $\mathrm{PH} 5$ and 7 where $\mathrm{OO}_{2} \mathrm{OH}^{+}$and $U \mathrm{O}_{2} \mathrm{CO}_{3}$ were the membrane $P H$ H humic acid (HA), uranium adsorption increased from $\mathrm{pH} 3(11 \%)$ to $\mathrm{pH} 7(74 \%)$ due to complexation. The structure of alginic acid (AA) did not favour complexation with uranium and therefore did not have a significant influence on its behaviour in UF. The exception was at $\mathrm{pH} 3$ where adsorption increased from $2 \%$ to $52 \%$. At this $\mathrm{pH}$ no charge repulsion between the uranium species and the AA occurs and complexation is favoured. The highest effect on uranium adsorption was obtained in the presence of tannic acid (TA) at pH 10 and 11 where adsorption increased from $20 \%$ up to 100\%. Uranium is most likely forming complexes with the gallic acid fraction of the dissociated TA.

Keywords: Uranium, Ultrafiltration, Organic Matter, Uranium-organic matter complexation Adsorption 
Semião, A. ; Rossiter, H.M.A. ; Schäfer, A.I. ; (2010) Impact of organic matter and speciation on the behaviour of uranium in submerged ultrafiltration, Journal of Membrane Science, 348, 1-2, 174-180.

\section{Introduction}

Uranium occurs naturally in the environment, both in geology and in water. Generally it is found in ground water at concentrations below $15 \mu \mathrm{g} / \mathrm{L}$, which is the WHO drinking water guideline [1]. Higher levels in ground and surface waters up to $1 \mathrm{mg} / \mathrm{L}[2]$ can, however, be found both naturally and due to anthropogenic activities such as mining and milling of uranium and other minerals [3]. High uranium concentrations are considered a health concern due to the natural radioactivity of the element and it chemical toxicity, which may cause damage to the kidneys and also accumulate in bone [4]. Uranium must therefore be removed from possible drinking water sources.

Uranium has a range of oxidation states of which +IV (uranous) and +VI (uranyl) are the most important [5]. In oxidising conditions uranium tends to be present as the uranyl ion $\left(\mathrm{UO}_{2}{ }^{2+}\right)$ [6]. The $\mathrm{pH}$ range of natural waters has been found to vary from $\mathrm{pH}_{2}$ ( $e g$. for acidic mine waters) up to $\mathrm{pH} 11$ (for saline waters) [5] and Important ligands complexes formed will deternine unanim behaviour. A variety of investigations explore possible structures of uranium complexed with different types of OM [10], though unfortunately these studies only focus on the lower end of the acidic $\mathrm{pH}$ range [11,12].

Due to the low operating energy required compared to nanofiltration and reverse osmosis, ultrafiltration (UF) is an attractive process for water treatment [13]. It has been shown that complexed uranium can be removed by UF with high retentions reported $[14,15]$. Considering that OM can be retained by UF to some extent [13] and influences the retention of metal ions [16, 17], an investigation into the removal of uranium-OM complexes by UF would therefore be valuable. For the purpose of this study three types of OM, representative of compounds found in natural waters, were chosen as suitable for further exploration: HA, AA and TA. HA accounts for a large portion of the natural OM extracted from rivers and streams [18]. AA was chosen as a representative of polysaccharides present in natural water (e.g. as brown algae (e.g. as bron a renova 23,24$]$. In fact he con reattint $[23,24]$. In fact $[16,17]$. TA is a cen to enhanced metal removal $[16,17]$. TA is a representative of plant polyphenols. Vegetable tannins are plant metabolites readily present in trees [25] and thus found in natural waters. TA is used as nucleation agent in textiles where it adsorbs/diffuses into the textile and then reduces the metals added, thereby attaching these to the textile structure [26]

The aim of this study was to investigate the influence of OM on uranium removal by UF across the $\mathrm{pH}$ range. This illustrated the influence of uranium speciation and complexation with $\mathrm{OM}$ on retentio mechanisms.

\section{Materials and Methods}

\subsection{UF membrane and set-up}

A schematic of the UF system used is shown in Figure 1. A GE Zenon ZeeWeed hollow fibre module (ZW1) was used in all the experiments. The nominal pore size of the membrane was $0.04 \mu \mathrm{m}$ and the membrane surface area was $0.047 \mathrm{~m}^{2}$. The membrane material is polyvinylidene fluoride (PVDF).

\section{[Figure 1]}

The module was operated in an "outside-in" configuration, submerged in $2.55 \mathrm{~L}$ of magnetically stirre feed solution and permeate was extracted by vacuum (constant flow rate of $50 \mathrm{~mL} / \mathrm{min}$ ) and recirculated back to the feed container. The peristaltic pump used to withdraw the permeate was a Masterflex Laboratory/Standard L/S with a digital variable-speed console drive with Masterflex Norprene L/S 16 tubing of inner diameter $3.1 \mathrm{~mm}$. Further equipment consisted of pressure transducer (PX219-30V45G5V) and a thermocouple (TJ2-CPSS-M6OU-200-SB) connected to a datalogger (OMB DAQ 54) for data recording (Omega, UK). Conductivity and $\mathrm{pH}$ were measured by using a $\mathrm{pH} /$ Cond 340i meter (WTW, Germany).

\subsection{Chemicals and reagents}

Four different experimental solutions were made (all containing a background electrolyte solution): 1) uranium without $\mathrm{OM}, 2$ ) uranium with $\mathrm{HA}, 3$ ) uranium with TA and 4) uranium with AA. The OM was purchased from Sigma Aldrich UK. A concentration of $25 \mathrm{mgC} / \mathrm{L}$ was used. Uranyl nitrate (TAAB $\mathrm{UK}$ ) was added to make up $0.5 \mathrm{mg} / \mathrm{L}$ uranium solution. The background electrolyte solution consisted of $1 \mathrm{mM} \mathrm{NaHCO} 3,0.5 \mathrm{mM} \mathrm{CaCl}_{2}$ and $10 \mathrm{mM} \mathrm{NaCl}$ all of analytical grade (Fisher Scientific, UK). To adjust the $\mathrm{pH}$ to the required levels $(\mathrm{pH} 3$ to $\mathrm{pH} 11), 1 \mathrm{M}$ analytical grade $\mathrm{HCl}$ or $\mathrm{NaOH}$ were used (Fisher Scientific, UK). Cleaning solutions were made up using $0.5 \mathrm{~g} / \mathrm{L}$ sodium dodecyl sulfate (SDS) (Sigma Aldrich, UK) and commercial bleach (Sainsbury's, UK).

\subsection{Organic matter properties}

The properties of the OM such as charge, size and functional groups influence uranium complexation The properties will also influence the OM interaction with the membrane. A general overview of the OM properties is given in Table 1. Important functional groups of HA include carboxylic, phenolic and alcoholic hydroxyls [27]. AA consists of linear polysaccharides containing mannuronic and galuronic acid ( $M$ and $G$, respectively) arranged in a non-regular block-wise order [19]. $M$ and $G$ block sequences $\left(\mathrm{F}_{\mathrm{MM}}, \mathrm{F}_{\mathrm{GG}}\right.$ and $\left.\mathrm{F}_{\mathrm{MG}}\right)$ display different structures and their proportions in the alginate determine the metal binding capacity. The lower the $\mathrm{M} / \mathrm{G}$ ratio and the higher the $\mathrm{F}_{\mathrm{GG}}$ content in the alginate, the higher the affinity to bind with metal ions $[19,22]$. TA is a hydrolysable tannin with a fundamental structure of glucose and gallic acid (GA) [25].

[Table 1] 
Semião, A. ; Rossiter, H.M.A. ; Schäfer, A.I. ; (2010) Impact of organic matter and speciation on the behaviour of uranium in submerged ultrafiltration, Journal of Membrane Science, 348, 1-2, 174-180.

\subsection{Filtration procedure}

The feed solution was prepared and $\mathrm{pH}$ adjusted 15 to 18 hours prior to the experiment to allow for the uranium and $\mathrm{OM}$ to equilibrate. Samples were taken before and after $\mathrm{pH}$ equilibration to confirm that there was no adsorption to the beaker. Conductivity, $\mathrm{pH}$, temperature and trans-membrane pressure were monitored hourly during the experiments, which lasted five hours. The first three parameter remained stable throughout the experiment. When $\mathrm{pH}$ changes occurred, online $\mathrm{pH}$ adjustments were carried out. Permeate and feed samples $(15 \mathrm{~mL})$ were collected hourly for inductively-coupled plasmaoptical emission spectroscopy ICP-OES $(5 \mathrm{~mL})$ and total organic carbon (TOC) analysis $(10 \mathrm{~mL})$.

Mem Membrane cleaning was conducted at the end of each experiment. The following protocol was used: MilliQ water backwash (15 min) to remove reversible fouling; nitric acid backwash (15 min) at $\mathrm{pH}<2$ to remove uranium; SDS backwash ( $15 \mathrm{~min}$ ) to remove OM, followed by a bleach backwash (30 min $10 \% \mathrm{v} / \mathrm{v}$ ) to further remove OM deposited on the membrane surface. AA was more difficult to remove and a $\mathrm{NaOH}$ backwash $(20 \mathrm{~min}, 0.02 \mathrm{M})$ was used in addition.

Analysis of the samples collected after the MilliQ water backwash allowed determination of the mas adsorbed corresponding to reversible fouling. The remaining mass adsorbed corresponded to irreversible fouling. Membrane deposition of uranium and OM was quantified by mass balance given by equation (1) and corrected for collected samples:

$$
\operatorname{Mass} \operatorname{Deposited}(\%)=\frac{\mathrm{V}_{\mathrm{F} 0} \mathrm{C}_{\mathrm{F} 0}-\mathrm{V}_{\mathrm{F} 5} \mathrm{C}_{\mathrm{F} 5}-\sum_{\mathrm{i}=0}^{\mathrm{i}=5} \mathrm{~V}_{\mathrm{S}} \mathrm{C}_{\mathrm{Fi}}-\sum_{\mathrm{i}=0}^{\mathrm{i}=5} \mathrm{~V}_{\mathrm{S}} \mathrm{C}_{\mathrm{Pi}}}{\mathrm{V}_{\mathrm{F} 0} \mathrm{C}_{\mathrm{F} 0}} \times 100
$$

Where $V_{F}$ is the feed volume $(L), C_{F}$ is the feed concentration $(g / L), C_{P}$ is the permeate concentration $(\mathrm{g} / \mathrm{L}), \mathrm{V}_{\mathrm{s}}$ is the sample volume (L) and i are the hourly collected samples (from 1 to 5 ).

\subsection{Analytical methods}

The samples and blanks for uranium analysis were stored in polypropylene centrifuge tubes $(15 \mathrm{~mL})$ acidified with nitric acid (Aristar, VWR International, UK) to $\mathrm{pH}<2$ and analyzed with ICP-OES (Perkin Elmer Optima 5300 DV, UK). Calibration standards were made using ICP uranium standar solution (Merck, Germany). The calibration was verified using a certified reference material (ICP Mult Element Standard Solution VI CertiPUR, Germany). The stability of the run was controlled by inserting check standards every 10 samples. Samples for TOC determination were kept in capped glass vials $(20 \mathrm{~mL})$ at $3-4{ }^{\circ} \mathrm{C}$ until they were analyzed. TOC was determined using a TOC analyze (Shimadzu TOC-V $\mathrm{V}, \mathrm{UK}$ ) with an ASI autosampler. Analyses were conducted in non-purgeable organic carbon mode (NPOC) used for low concentration samples.

\subsection{Solution speciation}

Speciation calculations were performed using Visual Minteq 2.53 (KTH, Stockholm, Sweden). Visual Minteq 2.53 which was updated in October 2007, uses the latest major review on thermodynamic dat on uranium. This includes a thermodynamic database for uranium and "generic" HA parameters [28]. Based on the ion composition of the experimental solutions, the speciation was calculated for each $\mathrm{pH}$ The dominant species predicted for each $\mathrm{pH}$ were then selected for a "sweep test" performed from $\mathrm{pH}$ $3-11$, at incremental steps of 0.5 . The $\mathrm{CO}_{2}$ was set to atmospheric pressure $\left(3.910^{-4} \mathrm{bar}\right)$ and temperature to $25^{\circ} \mathrm{C}$. For HA speciation, the Stockholm Humic Model (SHM) and NICA-Donnan model were both tested and compared to the experimental data. They both predicted HA to dominate the speciation at acidic to neutral $\mathrm{pH}$ (also found by [29]). Based on the correspondence with the experimental results the SHM model was chosen.

\section{Results and Discussions}

\subsection{Uranium retention}

The filtration of uranium over the $\mathrm{pH}$ range 3-11 was investigated as speciation affects the characteristics of uranium, the ligand formation between $\mathrm{OM}$ and uranium and the interactions between membrane and uranium species. This might affect retention by UF. However, uranium was not retained by the UF membrane (see Figure $2 \mathrm{~A}$ ) due to the size of uranium species $\left(\mathrm{UO}_{2}{ }^{2+}\right)$, which are much smaller $(\sim 1.8 \AA)[30]$ than the $0.04 \mu \mathrm{m}(400 \AA)$ membrane pore size.

\section{[Figure 2]}

The uranium complexes formed with TA and HA were also not retained (see Figure 2 B and D) and were thus smaller than the membrane pore size. An exception was with AA where a difference was observed between the final feed and permeate concentration of uranium (see Figure $2 \mathrm{C}$ ) and AA (not shown). Although AA was not expected to be retained based on its molecular radius of $16.2 \mathrm{~nm}$ [31], the final retention of AA ranged from 50 to $80 \%$ (data not shown) over the $\mathrm{pH}$ range studied. Retention of AA severely affected membrane performance, which indicated high fouling of the membrane (data not shown) as reported by several authors $[16,32,33]$. AA chains can become interconnected promoting gel network formation [19] thus decieasing me an increasing uranium retention. An important finding or this study was hat uranium concentration changed in the feed (and permeate) with time. For example, at $\mathrm{pH} 5$ and 7 (Figure $2 \mathrm{~A}$ ) uranium feed concentration decreases from $0.5 \mathrm{mg} / \mathrm{L}$ to less than $0.1 \mathrm{mg} / \mathrm{L}$ at the end of the experiment. This was attributed to membrane deposition or sorption and will be investigated in the following section.

\subsection{Uranium deposition on the membrane}

It is apparent that $70-80 \%$ of the uranium adsorbed to the membrane at $\mathrm{pH} 5$ and 7 (see Figure 3). Uranium deposition on the membrane could be explained by the characteristics of different species formed over the $\mathrm{pH}$ range (3-11), namely $\mathrm{UO}_{2}^{2+}, \mathrm{UO}_{2} \mathrm{OH}^{+}, \mathrm{UO}_{2} \mathrm{CO}_{3}, \mathrm{Ca}_{2} \mathrm{UO}_{2}\left(\mathrm{CO}_{3}\right)_{3}$ and $\mathrm{UO}_{2}\left(\mathrm{CO}_{3}\right)_{3}{ }^{4-}$ (see Figure 3). While at pH 3-5, $\mathrm{UO}_{2}{ }^{2+}$ is stable in solution, several other studies confirm significant adsorption of uranium around $\mathrm{pH} 5-7$ as $\mathrm{UO}_{2} \mathrm{OH}^{+}$starts to dominate, on a variety of media including natural subsurface media [34], polypropylene, Teflon and polycarbonate containers [35] and silica based materials. The authors explain the sorption mainly through ion exchange of the $\mathrm{UO}_{2} \mathrm{OH}^{+}$species based materials. The authors explain the sorption mainly through ion exchange of the $\mathrm{UO}_{2} \mathrm{OH}^{4}$ species easily for $\mathrm{UO}_{2} \mathrm{OH}^{+}$compared to $\mathrm{UO}_{2}^{2+}$. This was due to surrounding water molecules being less attracted to $\mathrm{UO}_{2} \mathrm{OH}^{+}$, allowing it to react with the surface of the studied material. The $\log K$ values (stability constants) can also indicate the tendency of a species to remain in solution. $\mathrm{UO}_{2} \mathrm{OH}^{+}$has the lowest $\log K$ value (-5.25), compared to other species predicted. At $\mathrm{pH} 7$ where adsorption to the membrane prevailed, $\mathrm{UO}_{2} \mathrm{CO}_{3}$ was predicted to dominate. This species is highly polar, displaying a ne positive charge by the uranium atom [39] and could thus adsorb to the membrane by electrostatic attraction. At pH 8-11 Ca $\mathrm{CO}_{2}\left(\mathrm{CO}_{3}\right)_{3}$ and $\mathrm{UO}_{2}\left(\mathrm{CO}_{3}\right)_{3}{ }^{4-}$ dominated. These are generally soluble in water 
$[3,5,40]$ and therefore no adsorption of uranium was observed at alkaline $\mathrm{pH}$. Although there was adsorption of uranium in the $\mathrm{pH}$ range studied this did not appear to affect membrane performance. The uranium species adsorbed were too small to cause any resistance to permeate flux. The possibility of uranium adsorption affecting membrane performance over a prolonged period of time was no investigated however

[Figure 3]

\subsection{Influence of organic matter on uranium deposition}

As seen in Figure 4 A uranium adsorption was not significantly affected by TA in the acid and neutral $\mathrm{pH}$ range as confirmed by Li et al. [41] at acidic $\mathrm{pH}$. The more dramatic effect was at $\mathrm{pH} 10$ and 11 , where an increase in uranium adsorption from less than $30 \%$ up to $100 \%$ occurred. This indicated that the presence of TA at high $\mathrm{pH}$ had a clear impact on the fate of uranium in the filtration process the presence of TA at high $\mathrm{pH}$ had a clear impact on the fate of uranium in the filtration process
through complexation between uranium and TA. Similarly, higher adsorption of metals to TA was found by Uçer et al. [42] with increasing $\mathrm{pH}$, possibly due to the dissociation of TA.

\section{[Figure 4]}

In the present study, a colour change took place during the alkaline $\mathrm{pH}$ adjustment of the TA solutions, from a clear solution to a dark green colour. Such colour change at alkaline $\mathrm{pH}$ was reported by Makkar and Becker [43], who determined a change in the TA solution without a change in phenolic content. In fact TA is easily degraded by water, acids, bases and certain enzymes to yield glucose and gallic acid $[25,44,45]$. It has been shown that metals attach to the galloyl part of the TA [46], which high $\mathrm{pH}$ dissociates into gallic acid. Gallic acid is known to complex with uranium [47]. Indeed precipitation of uranium from solution using hydrolysable $\mathrm{TA}$ at $\mathrm{pH} 10$ [48] has resulted in an adsorption of up to $80 \%$ uranium. Yoon et al. [49] described a method for uranium removal: TA extract and $\mathrm{CaCl}_{2}$ were added at alkaline $\mathrm{pH}$. The solution was sedimented, thereby removing uranium. Despite expecting charge repulsion between the negative uranium species at alkaline $\mathrm{pH}$ and the negatively charged gallic acid $\left(\mathrm{p} K_{\mathrm{a}}\right.$ in Table 1$)$ the $\mathrm{Ca}^{2+}$ ions present in the solution could potentially act as a bridge between gallic acid, the ligands on the uranium ion and the membrane.

Results in Figure 4 B show that the presence of AA enhanced adsorption of uranium at $\mathrm{pH}<5$. Under these conditions AA precipitates [20] and forms a gel that is compact due to reduced charge repulsion between the neutral molecules [50]. Since uranium is positive at this $\mathrm{pH}$ range (Figure 3), it is likely to form complexes with $\mathrm{AA}$ as opposed to more alkaline conditions when both uranium and $\mathrm{AA}$ are negatively cher. A AA. The AA stuen due to its zig-zag structure which can accommodate the metal ions $[19,20]$. This is known as the eggbox model $[19,20,22]$. Mycrocystis Pyrifera which is the AA species used in this study has one of the highest M/G ratios: 1.6-1.7 [20,22, 50], thus it is less favourable to metal binding compared to othe types of alginates available. Divalent metals have been found to be favoured by AA adsorption [19, 50 Considering that at $\mathrm{pH} 3-5$ the divalent species $\mathrm{UO}_{2}{ }^{2+}$ dominates this explains the high complexation by AA and consequent deposition of uranium. Metal size is also a key variable according to the eggbox model, due to the rigid nature of the GG linkages as well as the steric arrangement of the electronegative ions surrounding the metal. $\mathrm{Ca}^{2+}(1.00 \AA)$ has been found to be selectively favoured by AA over other metal ions [22]. Considering that the smallest species of uranium is found in the form of
$\mathrm{UO}_{2}{ }^{2+}$ with a radius of $1.8 \AA[30]$ and that at more alkaline conditions the uranium species are even larger $(4.85 \AA$ ) [51], complexation with AA would be less favoured in the neutral and alkaline $\mathrm{pH}$ range.

HA has an ability to interact with metal ions [27] as it contains voids which can trap and retain other components [27]. Carboxyl [52] and phenolic groups [53] present in HA have been found to be mportant for uranium-HA complexation. In the $\mathrm{pH}$ range 3-7, HA had a higher deposition compared to alkaline $\mathrm{pH}$ (Figure $4 \mathrm{C}$ ). At low $\mathrm{pH}, \mathrm{HA}$ is by definition insoluble $[18,54]$ and has a more compac configuration due to the reduced charge density (see Table 1) at both inter and intramolecular levels [55]. Using Visual Minteq, the complexation of uranium with HA was predicted to be dominated by HA between $\mathrm{pH}$ 3-7 (Figure 5), at which stage stable water soluble carbonate complexes become important. These speciation results confirmed experimental results where HA increased adsorption of uranium at $\mathrm{pH}$ 3-7 (Figure $4 \mathrm{C}$ and Figure 5). This also confirmed results from a variety of studies whe $\mathrm{HA}$ has been ficties (4) and increase uranium adsoption ont dis 列 decreased at $\mathrm{pH} 5$, but did not study uranium without OM to confirm whether or not this was due to the OM.

\section{[Figure 5]}

This study clearly shows the significant effect of the different types of OM in uranium removal by UF Solution characteristics such as $\mathrm{pH}$ and presence of $\mathrm{Ca}^{2+}$ determined whether complexation was favoured, enhancing adsorption of these complexes on the membrane.

\section{Conclusions}

The fate of uranium in the UF process was highly dependent on solution characteristics such as $\mathrm{pH}$ and type of OM. With the exception of AA, retention by size exclusion was not observed irrespective of the presence of OM. A significant amount of adsorption of uranium and uranium-OM complexes on the membrane was observed at certain conditions, for example at $\mathrm{pH} 5$ and 7 in the absence of OM. Stronger adsorption was observed when the uranium solution was filtered in presence of $\mathrm{HA}$ at $\mathrm{pH} 3$ to 7 , where according to speciation calculations, uranium formed complexes with the HA. The presence of AA did not affect uranium deposition significantly since the chosen alginate did not possess the necessary characteristics to bind metals. The adsorption of uranium was highest (75-100\%, $18.4-24.4$ $\mathrm{mg} / \mathrm{m}^{2}$ ) in presence of TA at $\mathrm{pH} 10$ and 11 where uranium was postulated to complex with gallic acid, originating from the dissociation of TA. Speciation calculation of uranium with HA was a useful tool to understand the results that were obtained in regards to the behaviour of uranium in the UF process. Current limitations are the availability of a variety of organic molecules in such databases. Significant findings from this study highlight that through simple adjustments to the water such as $\mathrm{pH}$ control and/or addition of complex forming molecules such as OM, uranium may be removed using UF. This process can be used as pre-treatment of NF/RO, where removal of these complexes by UF may help prevent scaling and organic fouling of the tighter membranes. Removal of metals such as uranium from industrial effluents (such as mining), uranyl in nuclear decommissioning related effluents or contaminated water supplies are applications where the influence of solution chemistry and OM are important. Further studies investigating the impact of co-precipitation on uranium removal by membrane filtration are warranted. 
Semião, A. ; Rossiter, H.M.A. ; Schäfer, A.I. ; (2010) Impact of organic matter and speciation on the behaviour of uranium in submerged ultrafiltration, Journal of Membrane Science, 348, 1-2, 174-180.

\section{Acknowledgements}

Studentships of Rossiter and Semião are funded by EPSRC-ESRC and the University of Edinburgh, respectively. We are grateful to Dr. Margaret Graham (School of Geosciences) and Dr Polly Arnold (School of Chemistry) for discussions on OM and uranium and to GE Zenon for provision of the membrane modules. We would also like to thank student John Davey for his contribution to setting up the UF systems and experimental development. Finally, we would like to thank Prof. Menachem Elimelech (Yale University) for a critical review of the paper.

\section{References}

WHO, Guidelines for drinking water quality, World Health Organisation, Geneva, 2006, p. 515.

12] A Abdelous, W. Lutze, E Nuttall Chemical reactions of uranium in ground water at a mill tailings site, J. Contam. Hydrol. 34 (1998) 343.

[3] F. Winde, I.J. van der Walt, The significance of groundwater-stream interactions and fluctuating stream chemistry on waterborne uranium contamination of streams - a case study from a gold mining site in South Africa, J. Hydrol. 287 (2004) 178

[4] P. Kurttio, H. Komulainen, A. Leino, L. Salonen, A. Auvinen, H. Saha, Bone as a possible target of chemical toxicity of natural uranium in drinking water, Environ. Health Perspect. 113 (2005) 68.

[5] D. Langmuir, Aqueous Environmental Geochemistry, Prentice Hall, Upper Saddle River, 1997.

[6] I. Grenthe, J. Fuger, R.J.M. Konings, R. Lemire, J., A.B. Muller, C. Nguyen-Trung Cregu, H. Wanner, Chemical thermodynamics of uranium, in: H. Wanner, I. Forest, (Eds), OECD Nuclear Energy Agency, Paris, 1992

[7] G. Bernhard, G. Geipel, V. Brendler, H. Nitsche, Uranium speciation in waters of different uranium mining areas, Journal of Alloys and Compounds. 271-273 (1998) 201.

[8] W.J. Li, J.J. Zhao, C.S. Li, S. Kiser, R.J. Cornett, Speciation measurements of uranium in alkaline waters using diffusive gradients in thin films technique, Anal. Chim. Acta. 575 (2006) 274.

[9] C. Kantar, Heterogeneous processes affecting metal ion transport in the presence of organic ligands: Reactive transport modeling, Earth Sci. Rev. 81 (2007) 175.

[10] N.M. Khai, I. Oborn, S. Hillier, J.P. Gustafsson, Modeling of metal binding in tropical Fluvisols and Acrisols treated with biosolids and wastewater, Chemosphere. 70 (2008) 1338

[11] P.G. Allen, D.K. Shuh, J.J. Bucher, N.M. Edelstein, T. Reich, M.A. Denecke, H. Nitsche, EXAFS determinations of uranium structures: The uranyl ion complexed with tartaric, citric, and malic acids, Inorg. Chem. 35 (1996) 784

[12] E.H. Bailey, J.F.W. Mosselmans, P.F. Schofield, Uranyl-citrate speciation in acidic aqueous solutions - an XAS study between 25 and 200 degrees C, Chem. Geol. 216 (2005) 1.

[13] C. Anselme, E.P. Jacobs, Ultrafiltration, in: J. Mallevialle, P.E. Odendaal, M.R. Wiesner, (Eds), Water Treatment Membrane Processes McGraw-Hill, New York, 1996, pp. 10.1-10.88.

[14] A.P. Kryvoruchko, L. Yu, I.D. Atamanenko, B.Y. Kornilovich, Ultrafiltration removal of U(VI) from contaminated water, Desalination. 162 (2004) 229

[15] E. Pramauro, A.B. Prevot, V. Zelano, M. Gulmini, G. Viscardi, Selective recovery of uranium(VI) from aqueous acid solutions using micellar ultrafiltration, Analyst. 121 (1996) 1401.

[16] N. Fatin-Rouge, A. Dupont, A. Vidonne, J. Dejeu, P. Fievet, A. Foissy, Removal of some divalent cations from water by membrane-filtration assisted with alginate, Water Res. 40 (2006) 1303
[17] O. Sanli, G. Asman, Removal of Fe (III) ions from dilute aqueous solutions by alginic acidenhanced ultrafiltration, J Appl. Polymer Sci. 77 (2000) 1096.

[18] Bourbonniere, V. Halderen, Fractional precipitation of humic acid from coloured natural waters, Water Air Soil Pollut. 46 (1989) 187

[19] T.A. Davis, B. Volesky, A. Mucci, A review of the biochemistry of heavy metal biosorption by brown algae, Water Res. 37 (2003) 4311.

[20] K.I. Draget, O. Smidsrød, G. Skjåk-Bræk, Alginates from algae, in: S. De Baets, E. Vandamme, A. Steinbüchel, (Eds), Biopolymers; Polysaccharides II: Polysaccharides from Eucaryotes 6, Whiley-VCH Verlag, Weinheim, Germany, 2002, pp. 215-244.

[21] D.J. Barker, D.C. Stuckey, A review of soluble microbial products (SMP) in wastewate treatment systems, Water Res. 33 (1999) 3063

[22] T.A. Davis, F. Llanes, B. Volesky, A. Mucci, Metal selectivity of Sargassum spp. and thei alginates in relation to their $\alpha$-L-guluronic acid content and conformation, Environ. Sci. Technol. 37 (2003) 261

[23] M.H. Khani, A.R. Keshtkar, M. Ghannadi, H. Pahlavanzadeh, Equilibrium, kinetic and thermodynamic study of the biosorption of uranium onto Cystoseria indica algae, J. Hazard. Mater. 150 (2008) 612.

[24] M.H. Khani, A.R. Keshtkar, B. Meysami, M.F. Zarea, R. Jalali, Biosorption of uranium from aqueous solutions bynonliving biomass of marinealgae Cystoseira indica, Electron. J. Biotechnol. 9 (2006) 100.

[25] I. Mueller-Harvey, Analysis of hydrolysable tannins, Anim. Feed Sci. Technol. 91 (2001) 3.

[26] W.J. Todd, Stable coloring by in situ formation of micro-particles United States Patent $6,136,044,2000$

[27] H.R. Schulten, A chemical structure for humic acid. Pyrolysis gas chromatography/mass spectrometry and pyrolysis-soft ionization mass spectrometry evidence, in: N. Senesi, T.M. Miano, (Eds), Humic substances in the global environment and implications on human health, Elsevier, Amsterdam, 1994, pp. 43-56.

[28] J.P. Gustafsson, J.W.J. van Schaik, Cation binding in a mor layer: batch experiments and modelling, Eur. J. Soil Sci. 54 (2003) 295

[29] E.R. Unsworth, P. Jones, S.J. Hill, The effect of thermodynamic data on computer model predictions of uranium speciation in natural water systems, J. Environ. Monit. 4 (2002) 528

[30] M.C. Duff, J.U. Coughlin, D.B. Hunter, Uranium co-precipitation with iron oxide minerals, Geochim. Cosmochim. Acta. 66 (2002) 3533.

[31] E. Worch, Eine neue Gleichung zur Berechnung von Diffusionskoeffizienten gelöster Stoffe, vom Wasser. 81 (1993) 289.

[32] D. Jermann, W. Pronk, S. Meylan, M. Boller, Interplay of different NOM fouling mechanism during ultrafiltration for drinking water production, Water Res. 41 (2007) 1713.

[33] D. Jermann, W. Pronk, M. Boller, A.I. Schäfer, The role of NOM fouling for the retention of estradiol and ibuprofen during ultrafiltration, J. Membr. Sci. 329 (2009) 75.

[34] M.O. Barnett, P.M. Jardine, S.C. Brooks, H.M. Selim, Adsorption and transport of uranium(VI) in subsurface media, Soil Sci. Soc. Am. J. 64 (2000) 908

[35] T.E. Payne, Uranium (VI) interactions with mineral surfaces: controlling factors and surface complexation modelling, PhD, University of New South Wales, 1999.

[36] J.D. Prikryl, A. Jain, D.R. Turner, R.T. Pabalan, Uranium(VI) sorption behavior on silicate mineral mixtures, J. Contam. Hydrol. 47 (2001) 241.

[37] M. Sutton, P. Warwick, A. Hall, Uranium(VI) interactions with OPC/PFA grout, J. Environ. Monit. 5 (2003) 922.

[38] A.M. Giblin, B.D. Batts, D.J. Swaine, Laboratory simulation studies of uranium mobility in natural waters, Geochim. Cosmochim. Acta. 45 (1981) 699. 
Semião, A. ; Rossiter, H.M.A. ; Schäfer, A.I. ; (2010) Impact of organic matter and speciation on the behaviour of uranium in submerged ultrafiltration, Journal of Membrane Science, 348, 1-2, 174-180. doi:10.1016/j.memsci.2009.10.056

[39] D. Majumdar, S. Roszak, K. Balasubramanian, H. Nitsche, Theoretical study of aqueous uranyl carbonate (UO2CO3) and its hydrated complexes: $\mathrm{UO} 2 \mathrm{CO} 3 \cdot \mathrm{nH} 2 \mathrm{O}(\mathrm{n}=1-3)$, Chem. Phys. Lett. $372(2003) 232$.

[40] M.C. Duff, C. Amrhein, Uranium(VI) adsorption on goethite and soil in carbonate solutions, Soil Sci. Soc. Am. J. 60 (1996) 1393

[41] W.C. Li, D.M. Victor, C.L. Chakrabarti, Effect of $\mathrm{pH}$ and uranium concentration on interaction of uranium(VI) and uranium(IV) with organic-ligands in aqueous-solutions, J. Anal. Chem. 52 (1980) 520.

[42] A. Üçer, A. Uyanik, Ş.F. Aygün, Adsorption of $\mathrm{Cu}(\mathrm{II}), \mathrm{Cd}(\mathrm{II}), \mathrm{Zn}(\mathrm{II}), \mathrm{Mn}(\mathrm{II})$ and $\mathrm{Fe}(\mathrm{III})$ ions by tannic acid immobilised activated carbon, Sep. Purif. Technol. 47 (2006) 113.

[43] H.P.S. Makkar, K. Becker, Effect of $\mathrm{pH}$, temperature, and time on inactivation of tannins and possible implications in detannification studies, J. Agric. Food Chem. 44 (1996) 1291

[44] E. Haslam, Chemistry of vegetable tannins, Academic Press London and New York, 1966.

D.K. Salunkhe, J.K. Chavan, S.S. Kadam, Dietary tannins: consequences and remedies, CRC Press, Boca Raton, 1990.

[46] A.R.S. Ross, M.G. Ikonomou, K.J. Orians, Characterization of dissolved tannins and their metal-ion complexes by electrospray ionization mass spectrometry, Anal. Chim. Acta. 411 (2000) 91 .

[47] J.L. Domingo, A. Ortega, J.M. Llobet, J. Corbella, Effectiveness of chelation-therapy with time after acute uranium intoxication, Fundam. Appl. Toxicol. 14 (1990) 88.

[48] W. Shirato, Y. Kamei, Method for adsorbing and separating heavy metal elements by using a tannin adsorbent and method of regenerating the adsorbent United States Patent 5,460,791, 1995.

[49] M. Yoon, S. Whang, C. Insoon, P. Han, Recovery or removal of uranium by the utilization of acorns US Patent 4,871,518, 1989.

[50] S. Lee, M. Elimelech, Relating organic fouling of reverse osmosis membranes to intermolecular adhesion forces, Environ. Sci. Technol. 40 (2006) 980.

[51] A. Favre-Reguillon, G. Lebuzit, J. Foos, A. Guy, M. Draye, M. Lemaire, Selective

concentration of uranium from seawater by nanofiltration, Ind. Eng. Chem. Res. 42 (2003) 5900

52] K. Schmeide, S. Sachs, M. Bubner, T. Reich, K.H. Heise, G. Bernhard, Interaction of uranium(VI) with various modified and unmodified natural and synthetic humic substances studied by EXAFS and FTIR spectroscopy, Inorg. Chim. Acta. 351 (2003) 133.

[53] S. Pompe, K. Schmeide, M. Bubner, G. Geipel, K.H. Heise, G. Bernhard, H. Nitsche, Investigation of humic acid complexation behavior with uranyl ions using modified synthetic and natural humic acids, Radiochim. Acta. 88 (2000) 553.

[54] K. Ghosh, M. Schnitzer, Macromolecular structures of humic substances, Soil Sci. 129 (1980) 266.

[55] E. Balnois, K.J. Wilkinson, J.R. Lead, J. Buffle, Atomic force microscopy of humic substances: effects of pH and ionic strength, Environ. Sci. Technol. 33 (1999) 3911

[56] T.E. Payne, J.A. Davis, T.D. Waite, Uranium adsorption on ferrihydrate - effects of phosphate and humic acid, Radiochim. Acta. 74 (1996) 239.

[57] J.J. Lenhart, B.D. Honeyman, Uranium(VI) sorption to hematite in the presence of humic acid, Geochim. Cosmochim. Acta. 63 (1999) 2891

[58] F.Z. Erdemgil, S. Sanli, N. Sanli, G. Ozkan, J. Barbosa, J. Guiteras, J.L. Beltran, Determination of $\mathrm{pKa}$ values of some hydroxylated benzoic acids in methanol-water binary mixtures by LC methodology and potentiometry, Talanta. 72 (2007) 489.

[59] K. Polewski, S. Kniat, D. Slawinska, Gallic acid, a natural antioxidant, in aqueous and micellar environment: spectroscopic studies, Water Air Soil Pollut. 26 (2002) 217.
[60] H.R. Schulten, N. Schnitzer, A state of the art structural concept for humic substances, Naturwissenschaften. 80 (1993) 29.

[61] H.-S. Shin, J.M. Monsallier, G.R. Choppin, Spectroscopic and chemical characterizations of molecular size fractionated humic acid, Talanta. 50 (1999) 641. 
Semião, A. ; Rossiter, H.M.A. ; Schäfer, A.I. ; (2010) Impact of organic matter and speciation on the behaviour of uranium in submerged ultrafiltration, Journal of Membrane Science, 348, 1-2, 174-180. doi:10.1016/j.memsci.2009.10.056

Table 1 Organic matter properties

\begin{tabular}{|c|c|c|c|}
\hline Compound & Molecular Structure & $\begin{array}{c}\text { Molecular Weight } \\
(\mathrm{g} / \mathrm{mol})\end{array}$ & pKa (- ) \\
\hline Alginic Acid & 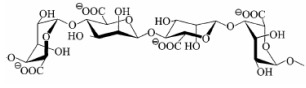 & $12,000-80,000^{[50]}$ & $3.44^{[19,20]}$ \\
\hline Gallic Acid & & 170 & $3.13-9.2^{[58,59]}$ \\
\hline Humic Acid & Proposed structure in [60] & $1000->300,000^{[6]]}$ & $3.5-5.04^{[61]}$ \\
\hline Tannic Acid & & 1701 & - \\
\hline
\end{tabular}

\section{List of figures}

Figure 1 Ultrafiltration submerged system (P: pressure transducer, T: thermocouple)

Figure 2 Uranium final feed and permeate concentration with different $\mathrm{OM}$ types (at $\mathrm{t}=5 \mathrm{~h}$ ). A) withou OM, B) TA, C) AA and D) HA. Feed solution: $0.5 \mathrm{mgU} / \mathrm{L}$ as $\mathrm{UO}_{2}\left(\mathrm{NO}_{3}\right)_{2}, 1 \mathrm{mM} \mathrm{NaHCO}, 0.5 \mathrm{mM}$ $\mathrm{CaCl}_{2}, 10 \mathrm{mM} \mathrm{NaCl}, 25 \mathrm{mgC} / \mathrm{L}$ OM. All error bars represent the relative error calculated from three repeat experiments.

Figure 3 Uranium membrane deposit ( $\mathrm{at} \mathrm{t}=5 \mathrm{~h}$ ) and uranium speciation in absence of $\mathrm{OM}$ as a function of $\mathrm{pH}$. Feed solution: $0.5 \mathrm{mgU} / \mathrm{L}$ as $\mathrm{UO}_{2}\left(\mathrm{NO}_{3}\right)_{2}, 1 \mathrm{mM} \mathrm{NaHCO}_{3}, 0.5 \mathrm{mM} \mathrm{CaCl} 2,10 \mathrm{mM} \mathrm{NaCl}$.

Figure 4 Uranium and organic matter membrane deposit (at $t=5 h$ ) for A) TA, B) AA and C) HA. Feed solution: $0.5 \mathrm{mgU} / \mathrm{L}$ as $\mathrm{UO}_{2}\left(\mathrm{NO}_{3}\right)_{2}, 1 \mathrm{mM} \mathrm{NaHCO}_{3}, 0.5 \mathrm{mM} \mathrm{CaCl}_{2}, 10 \mathrm{mM} \mathrm{NaCl}, 25 \mathrm{mgC} / \mathrm{L} \mathrm{OM}$.

Figure 5 Uranium membrane deposit (at $\mathrm{t}=5 \mathrm{~h}$ ) and speciation of uranium-HA solution as a function of $\mathrm{pH}$. The solution speciated was $0.5 \mathrm{mgU} / \mathrm{L}$ as $\mathrm{UO}_{2}\left(\mathrm{NO}_{3}\right)_{2}, 1 \mathrm{mM} \mathrm{NaHCO}_{3}, 0.5 \mathrm{mM} \mathrm{CaCl}_{2}, 10 \mathrm{mM}$ $\mathrm{NaCl}, 25 \mathrm{mgC} / \mathrm{L} \mathrm{HA}$ (HA from the Minteq data base). 
Semião, A. ; Rossiter, H.M.A. ; Schäfer, A.I. ; (2010) Impact of organic matter and speciation on the behaviour of uranium in submerged ultrafiltration, Journal of Membrane Science, 348, 1-2, 174-180. doi:10.1016/j.memsci.2009.10.056

Figure 1

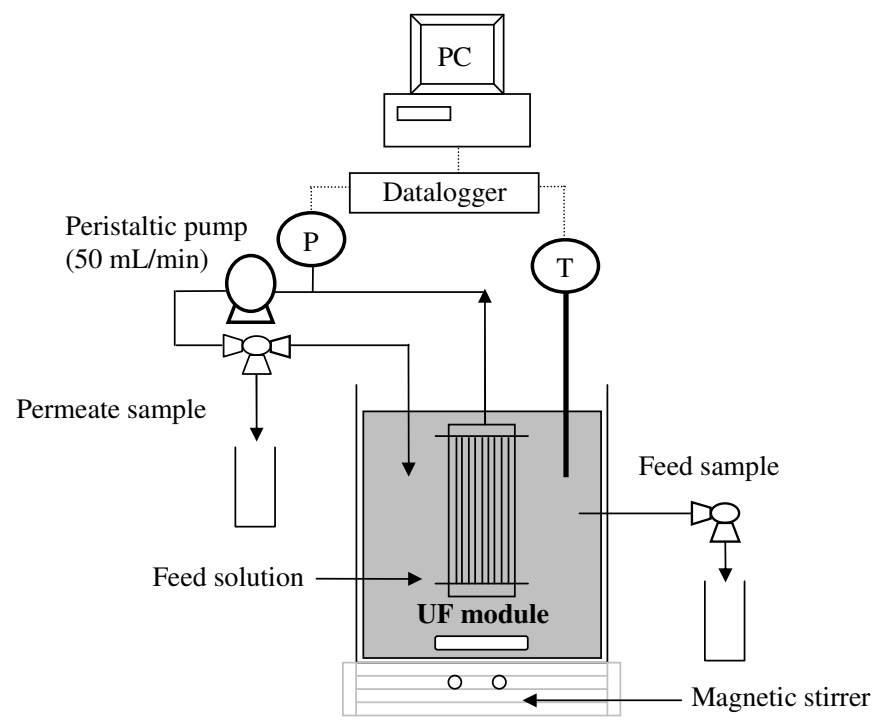

Figure 2

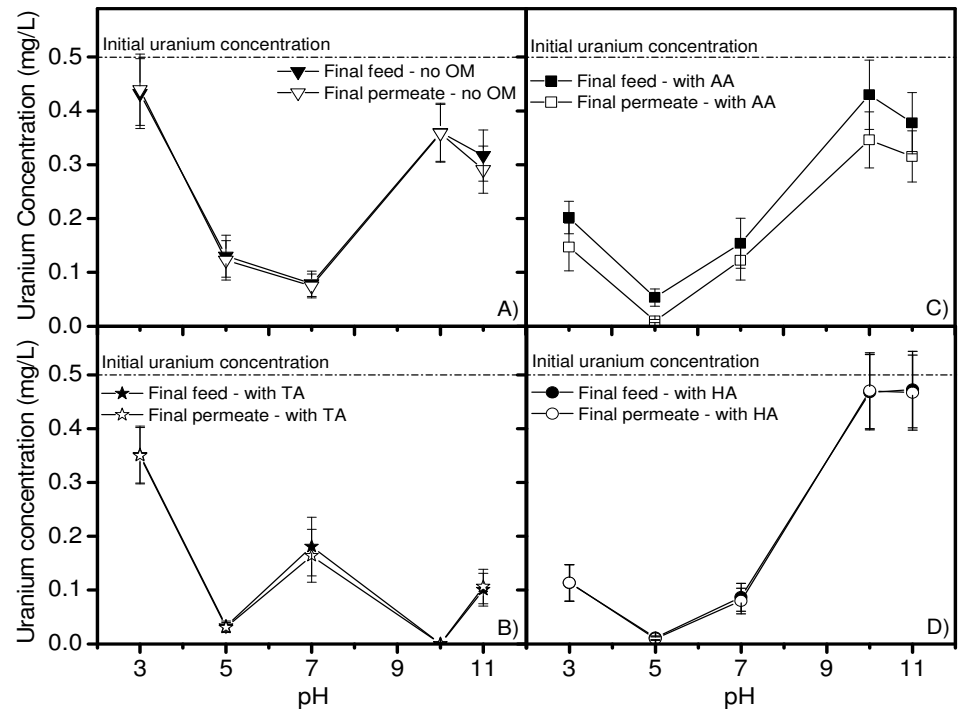


Semião, A. ; Rossiter, H.M.A. ; Schäfer, A.I. ; (2010) Impact of organic matter and speciation on the behaviour of uranium in submerged ultrafiltration, Journal of Membrane Science, 348, 1-2, 174-180. doi:10.1016/j.memsci.2009.10.056

Figure 3

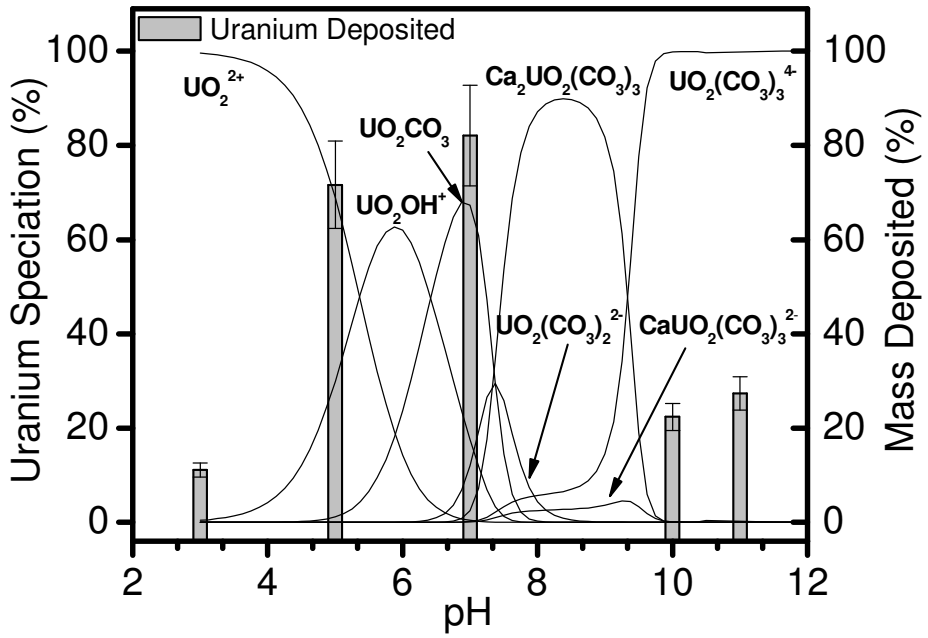

Figure 4
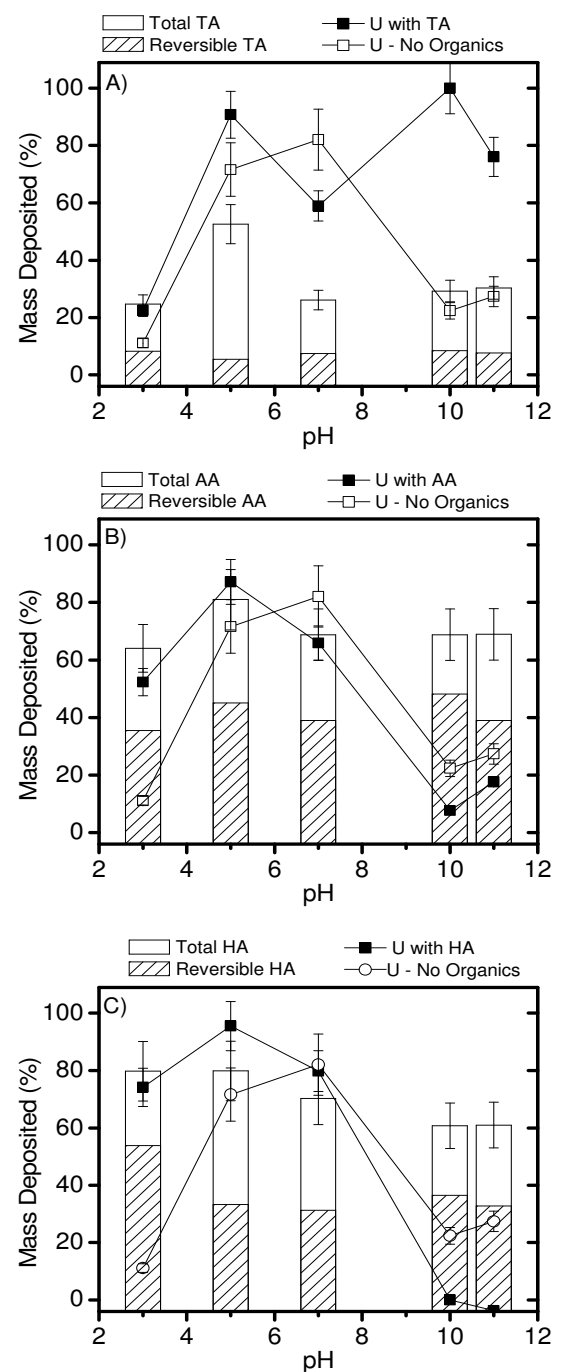
Semião, A. ; Rossiter, H.M.A. ; Schäfer, A.I. ; (2010) Impact of organic matter and speciation on the behaviour of uranium in submerged ultrafiltration, Journal of Membrane Science, 348, 1-2, 174-180. doi:10.1016/j.memsci.2009.10.056

Figure 5

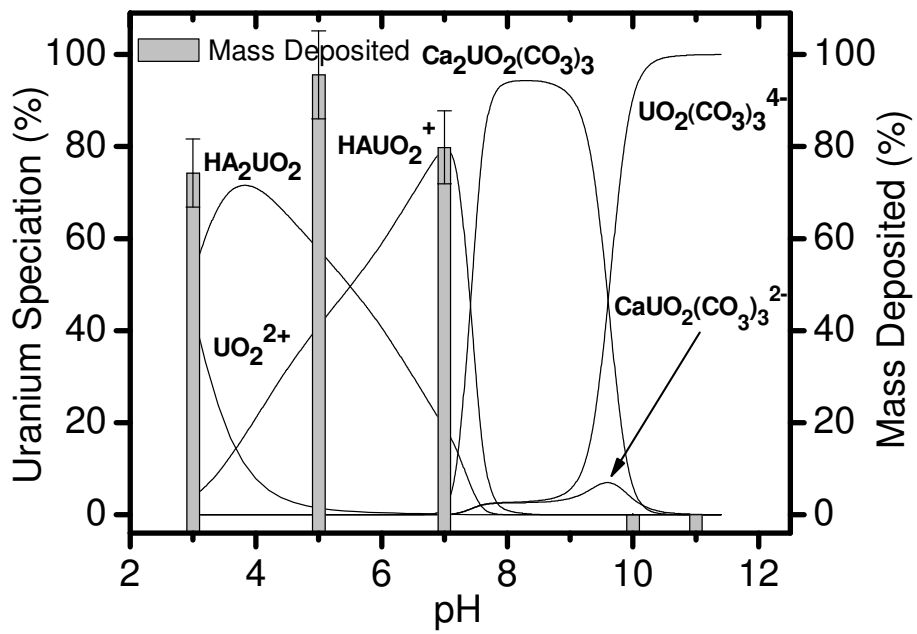

